\title{
Activation of liver $X$ receptors inhibits pancreatic islet beta cell proliferation through cell cycle arrest
}

\author{
Z. X. Meng • J. Nie • J. J. Ling • J. X. Sun • Y. X. Zhu • \\ L. Gao $\cdot$ J. H. Lv • D. Y. Zhu $\cdot$ Y. J. Sun $\cdot$ X. Han
}

Received: 25 June 2008 / Accepted: 9 September 2008 / Published online: 24 October 2008

(C) Springer-Verlag 2008

\begin{abstract}
Aims/hypothesis Liver X receptors (LXRs) are important transcriptional regulators of lipid homeostasis and proliferation in several cell types. However, the roles of LXRs in pancreatic beta cells have not been fully established. The aim of this study was to investigate the effects of LXRs on pancreatic beta cell proliferation.

Methods Gene expression was analysed using real-time RTPCR. Transient transfection and reporter gene assays were used to determine the transcriptional activity of LXRs in pancreatic beta cells. Cell viability and proliferation were analysed using 3-(4,5-dimethylthiazol-2-yl)-2,5-diphenyltetrazolium bromide (MTT), DNA fluorometric, BrdU labelling and $\left[{ }^{3} \mathrm{H}\right]$ thymidine incorporation assays. Cell cycle distribution was investigated by flow cytometry analysis. Adenovirus-based RNA interference was used to knockdown LXR $\alpha, L X R \beta$ and p27 in MIN6 cells and mouse islets.
\end{abstract}

Electronic supplementary material The online version of this article (doi:10.1007/s00125-008-1174-x) contains supplementary material, which is available to authorized users.

Z. X. Meng $\cdot$ J. Nie $\cdot$ J. J. Ling $\cdot$ Y. X. Zhu $\cdot$ L. Gao $\cdot$ J. H. Lv $\cdot$

Y. J. Sun $\cdot X$. Han $(\varangle)$

Key Laboratory of Human Functional Genomics of Jiangsu

Province, Clinical Diabetes Centre of Jiangsu Province,

Nanjing Medical University,

140 Hanzhong Road,

Nanjing 210029, People's Republic of China

e-mail: hanxiao@njmu.edu.cn

J. X. Sun

Model Animal Research Centre, Nanjing University,

Nanjing, People's Republic of China

D. Y. Zhu

School of Pharmacy, Nanjing Medical University,

Nanjing, People's Republic of China
Results We found that both Lxr (also known as Nrlh3) and $\operatorname{Lxr} \beta$ (also known as NrIh2) were expressed and transactivated the LXR response element in HIT-T15 and MIN6 cells. Activation of LXRs dose-dependently inhibited pancreatic beta cell viability and proliferation. This was accompanied by beta cell cycle arrest at the G1 phase. Furthermore, LXR activation increased levels of the p27 protein by inhibiting its degradation. Knockdown of p27 reversed these effects of LXR activation on growth inhibition and cell cycle arrest.

Conclusions/interpretation Our observations indicate that LXR activation inhibits pancreatic beta cell proliferation through cell cycle arrest. A well-known regulator of pancreatic beta cell cycle progression, $\mathrm{p} 27$, is upregulated and mediates the effects of LXRs on growth inhibition in beta cells. These observations suggest the involvement of aberrant activation of LXR in beta cell mass inadequacy, which is an important step in the development of type 2 diabetes.

Keywords Beta cell · Cell cycle · Islet · LXR · p27 · Proliferation

$\begin{array}{ll}\text { Abbreviations } \\ \text { CMV } & \text { cytomegalovirus } \\ \text { GFP } & \text { green fluorescent protein } \\ \text { LXR } & \text { liver X receptor } \\ \text { LXRE } & \text { liver X receptor response element } \\ \text { MTT } & \text { 3-(4,5-dimethylthiazol-2-yl)-2,5-diphenyltetrazo- } \\ & \text { lium bromide } \\ \text { RNAi } & \text { RNA interference } \\ \text { SKP2 } & \text { S-phase kinase-associated protein } 2 \\ \text { SiRNA } & \text { small interfering RNA } \\ \text { T1317 } & \text { T0901317 }\end{array}$




\section{Introduction}

Type 2 diabetes is a chronic disease arising from a combination of insulin resistance and defective insulin secretion [1-3]. During earlier stages of this disease, beta cells are able to maintain normoglycaemia through expansion of beta cell mass and enhanced insulin secretion. However, with the onset of insulin resistance, blood glucose and lipid levels become elevated, resulting in a progressive deterioration of beta cell function, which is associated with a loss of beta cell mass [3]. Progression to full-blown diabetes occurs when insulin hypersecretion by pancreatic beta cells fails to compensate for insulin resistance [1]. However, the mechanisms underlying this process remain poorly understood.

Beta cell mass plays an essential role in determining the amount of insulin that is secreted to maintain the body's glucose levels within a narrow range [4]. Regulation of beta cell mass represents a critical issue for understanding diabetes. There is considerable debate in the literature regarding the source of cells for islet expansion in adults. Recent evidence suggests that the beta cell population is not maintained by stem cells but by the replication of differentiated beta cells in adult rodents [5], and that all beta cells contribute equally to the growth and maintenance of the beta cell mass [6]. Recent gene inactivation studies have revealed that cell cycle regulators play an essential role in regulating beta cell mass in adult rodents [7]. Because it inhibits cyclin-dependent kinase activity, p27 has recently been recognised as an important beta cell cycle regulator. Both transcriptional and post-translational mechanisms are involved in the regulation of cellular levels of p27. The S-phase kinase-associated protein 2 (SKP2)mediated ubiquitin proteolytic pathway plays an essential and specific role in regulating p27 levels in pancreatic beta cells and is a critical determinant of beta cell proliferation [8]. Both overall and nuclear levels of p27 are increased in beta cells of some mouse models of type 2 diabetes [9]. Overproduction of p27 in beta cells leads to severe diabetes through a decrease in beta cell mass resulting from inhibition of beta cell proliferation $[8,9]$. Deletion of $\mathrm{p} 27$ in these models prevents the development of overt hyperglycaemia and increases both islet mass and serum insulin concentration by stimulating beta cell proliferation [9]. Thus, manipulation of cell cycle regulators such as p27 during the development of type 2 diabetes can potentially restore islet mass $[10,11]$.

The liver X receptors $\alpha$ and $\beta$ (LXR $\alpha$ and LXR $\beta$, respectively) are oxysterol-activated nuclear receptors [12]. Lxr $\alpha$ (also known as $N r 1 h 3$ ) is primarily expressed in the liver, intestine, adipose tissue and macrophages, whereas $\operatorname{Lxr} \beta$ (also known as Nr1h2) is ubiquitously expressed [13]. LXRs have been shown to play an important role in the control of cellular and whole body cholesterol homeostasis [13]. Previous studies have reported that levels of LXR $\alpha$ and LXR $\beta$ are elevated in the pancreatic beta cells of rodent models of type 2 diabetes and these receptors have been implicated as important regulators of glucose and insulin metabolism [14 16]. In addition, it has been recently reported that activation of LXRs by T0901317 (T1317), a synthetic agonist, inhibits the proliferation of cancer cells [17] and vascular smooth muscle cells [18], partially through p27 protein level upregulation. However, the role of LXRs in the regulation of pancreatic beta cell proliferation is not clear.

Based on the results described above, the aim of the present study was to investigate the effects of LXRs on pancreatic beta cell proliferation using the beta cell lines HIT-T15 and MIN6 and isolated mouse islets.

\section{Methods}

\section{Reagents}

For a list of reagents and suppliers, see the Electronic supplementary material (ESM).

\section{Cell culture}

Hamster HIT-T15 and mouse MIN6 cell lines were established as described previously $[19,20]$. The cell culture method is described in detail in the ESM. Both HIT-T15 and MIN6 cells exhibit glucose-inducible insulin secretion and retain the physiological characteristics of normal beta cells. Two cell lines from different species were used to verify that the effects of LXRs on beta cells were not species-specific. However, since mRNA sequences are not available for the majority of hamster genes, the gene expression analyses were solely performed in mouse MIN6 cells.

Islet isolation and culture

All animal studies were performed according to guidelines established by the Research Animal Care Committee of Nanjing Medical University. Male ICR mice (20-25 g; purchased from Shanghai Laboratory Animal Centre, Chinese Academy of Sciences, Shanghai, People's Republic of China) were used. Islet isolation and culturing techniques have been described previously [21]. Freshly isolated islets were transferred to sterile six well plates and cultured in DMEM containing $11.1 \mathrm{mmol} / \mathrm{l}$ glucose supplemented with $10 \%$ FBS. The islets were allowed to equilibrate for $3 \mathrm{~h}$, after which they were counted and repicked into six well plates (400 islets per well for RNA or protein extraction) or 24 well plates (50 islets per well for $\left[{ }^{3} \mathrm{H}\right]$ thymidine incorporation assays) and cultured overnight at $37^{\circ} \mathrm{C}$ for further studies. 
Transient transfection and luciferase reporter assay

The luciferase reporter construct LXRE×3-TK-LUC was transiently transfected without or with pcDNA3, pcDNA3hLXR $\alpha$ or pcDNA3-hLXR $\beta$ [22] into HIT-T15 or MIN6 cells grown in 24 well plates using the Lipofectamine 2000 reagent according to the manufacturer's instructions. A plasmid expressing the gene encoding $\beta$-galactosidase driven by the cytomegalovirus (CMV) promoter (Clontech Laboratories, Palo Alto, CA, USA) was simultaneously cotransfected as an internal control. The medium was replaced $4 \mathrm{~h}$ after transfection. Twenty-four hours after transfection, the cells were treated with the indicated concentrations of LXR agonists for an additional $24 \mathrm{~h}$ and harvested for luciferase reporter assays as described previously [21].

\section{Real-time RT-PCR assay}

MIN6 cells and isolated mouse islets were cultured and treated as described above. The total RNA was extracted using Trizol reagent. First-strand cDNA synthesis was per- formed using $1 \mu \mathrm{g}$ of total RNA and an avian myeloblastosis virus reverse transcription system. The primers were designed using primer express software (Applied Biosystems, Foster City, CA, USA). Real-time quantitative PCR was performed using the SYBR Green PCR Master Mix and ABI Prism 7000 Sequence Detection System (Applied Biosystems). All data were analysed using the expression of the gene encoding $\beta$-actin as a reference. The sequences of the primers used are available upon request.

\section{Adenovirus-mediated RNAi}

The sequences of DNA nucleotides used to create mouse small interfering RNA (siRNA) were the same as used previously [23-25] and are shown in ESM Table 1. The sequences were synthesised, annealed and subcloned into pShuttle-H1 according to the method of Shen et al. [26]. To allow infection efficiency to be conveniently monitored, the H1 siRNA fragments were cut from pShuttle-H1 and ligated into the pAdTrack-CMV plasmid upstream of the CMV-green fluorescent protein (GFP) cassette. The AdTrack-H1 siRNA plasmid was recombined with back- a

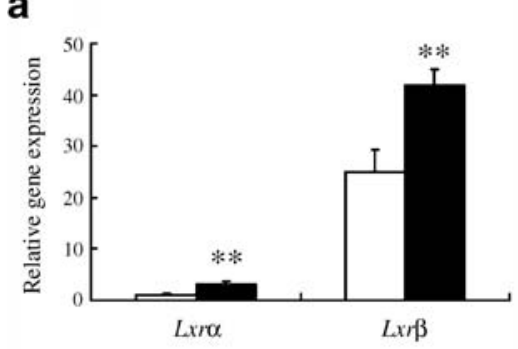

b

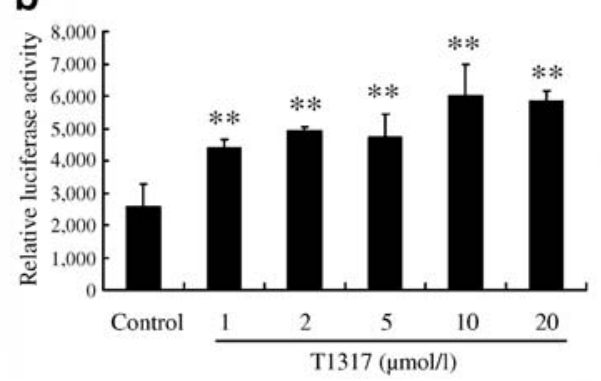

e

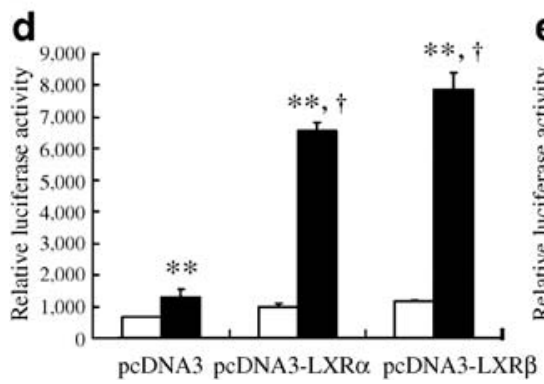



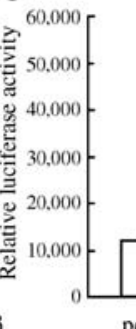

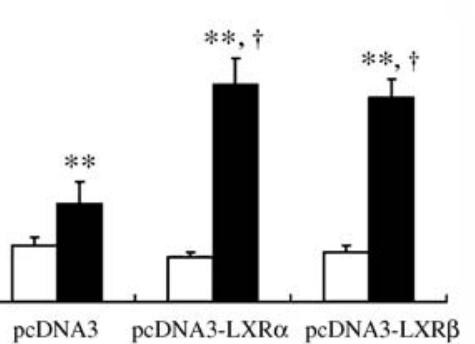

C

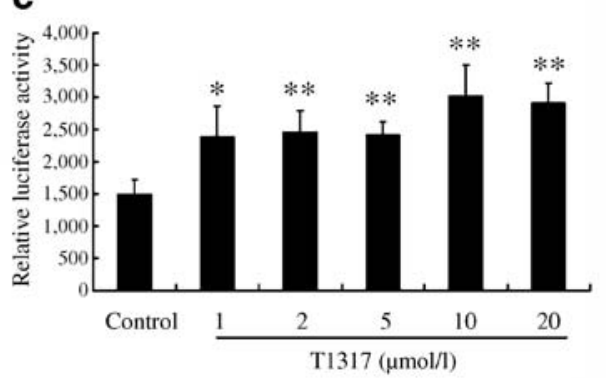

f

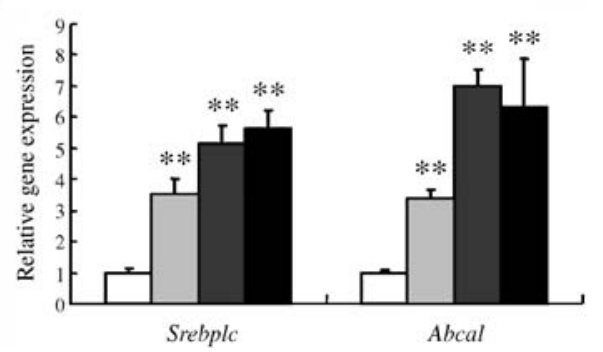

Fig. 1 LXRs are produced and are functionally active in pancreatic beta cells. a After being treated without (control, white bars) or with T1317 (10 $\mu \mathrm{mol} / 1$, black bars) for $48 \mathrm{~h}$, levels of $L X R \alpha$ and $L X R \beta$ mRNA were analysed using real-time RT-PCR assays and normalised to $\beta$-actin levels. HIT-T15 (b) and MIN6 (c) cells were transiently transfected with LXRE $\times 3-T K-L U C$ and treated without (control) or with the indicated concentrations of T1317 for $24 \mathrm{~h}$. LXRE $\times 3-T K-$ LUC was transiently cotransfected with pcDNA3, pcDNA3-hLXR $\alpha$ or pcDNA3-hLXR $\beta$ into HIT-T15 (d) or MIN6 (e) cells and treated without (control, white bars) or with $\mathrm{T} 1317$ (10 $\mu \mathrm{mol} / \mathrm{l}$, black bars) for $24 \mathrm{~h}$. $\beta$-Galactosidase plasmids were cotransfected in all of the above experiments as an internal control. The relative values of LXRE luciferase activity to $\beta$-galactosidase are shown as means \pm SEM of three independent experiments. f T1317 induced the expression of typical LXR target genes in beta cells. MIN6 cells were treated without (control, white bars) or with $5 \mu \mathrm{mol} / 1$ (light grey bars), $10 \mu \mathrm{mol} / \mathrm{l}$ (dark grey bars) and $20 \mu \mathrm{mol} / \mathrm{l}$ (black bars) of T1317 for $48 \mathrm{~h}$, followed by RNA extraction and real-time RT-PCR assays to determine the Srebplc and Abcal mRNA levels. The expression levels relative to $\beta$-actin are presented as the means \pm SEM of three separate experiments. ${ }^{*} p<0.05, * * p<0.01$ vs control; ${ }^{\dagger} p<0.01$ vs corresponding responses in cells cotransfected with control vector pcDNA3 and treated with T1317 $(10 \mu \mathrm{mol} / \mathrm{l})$ 
bone pAdEasy-1 in BJ5183 bacteria. Adenovirus generation, amplification, and titration were performed as described previously [27]. Viral particles were purified using the Virabind Adenovirus Purification Kit (Cell Biolabs, San Diego, CA, USA). MIN6 cells and isolated mouse islets were infected with adenovirus at a multiplicity of infection of 50 at $37^{\circ} \mathrm{C}$ and, $2 \mathrm{~h}$ after infection, the cells and islets were cultured in fresh medium for another $18 \mathrm{~h}$ before treating with $\mathrm{T} 1317(10 \mu \mathrm{mol} / \mathrm{l})$ for $48 \mathrm{~h}$.

\section{Cell viability assay}

Cell viability was determined using a 3-(4,5-dimethylthiazol- 2-yl)-2,5-diphenyltetrazolium bromide (MTT) assay as described previously [28].

\section{Cell proliferation assay}

The three different methods described below were used to confirm the effects of LXR agonists on the proliferation of pancreatic beta cells.

DNA fluorometric assay Cell number was determined using DNA fluorometric assays in which DNA content was measured using the fluorescent dye Hoechst 33258 (Sigma Aldrich, St Louis, MO, USA) as described previously [29]. Fluorescence intensities were obtained using a SpectraMax Gemini EM fluorescent plate reader (Molecular Devices, Sunnyvale, CA, USA) at excitation and emission wavelengths of 350 and $460 \mathrm{~nm}$, respectively.

BrdU labelling assay DNA synthesis was analysed using BrdU Labelling and Detection Kit I (Roche, Nonenwald, Germany) as described in the ESM. At least ten random fields per coverslip were counted for the labelled cells in three separate experiments using confocal microscopy. The BrdU labelling index was defined as the ratio of the number of BrdU-positive nuclei to the total number of nuclei within the fields.

$\left[{ }^{3} H\right]$ Thymidine incorporation assay The incorporation of $\left[{ }^{3} \mathrm{H}\right]$ thymidine into islet DNA was measured as described in the ESM.

Flow cytometry analysis

HIT-T15 and MIN6 cells were seeded and cultured in six well plates at a concentration of $1 \times 10^{6}$ cells per well. HITT15 cells were treated without (control) or with T1317 or another LXR agonist, GW3965, at a concentration of 5, 10 or $20 \mu \mathrm{mol} / 1$ for $48 \mathrm{~h}$. MIN6 cells were infected with adenoviruses at a multiplicity of infection of 50 and treated with $\mathrm{T} 1317(10 \mu \mathrm{mol} / \mathrm{l})$ for $48 \mathrm{~h}$. The cells in each well were then harvested for flow cytometry analyses as described previously [28].

Western blot analysis

HIT-T15 and MIN6 cells and isolated mouse islets were cultured and treated as described above, and the lysed with ice-cold lysis buffer containing $50 \mathrm{mmol} / \mathrm{l}$ Tris-HCl, pH 7.4; $1 \%$ NP-40; 150 mmol/l NaCl; 1 mmol/l EDTA; $1 \mathrm{mmol} / \mathrm{l}$ phenylmethylsulphonyl fluoride; and complete proteinase inhibitor mixture (one tablet per $10 \mathrm{ml}$; Roche Molecular Biochemicals, Indianapolis, IN, USA). After protein content determination using a DC Protein Assay kit (Bio-Rad Laboratories, Hercules, CA, USA), western blotting was performed as described previously [28].

Statistical analysis

Comparisons were performed using the Student's $t$ test for two groups, or ANOVA for multiple groups. Results are presented as means \pm SEM. A $p$ value of less than 0.05 was considered statistically significant.
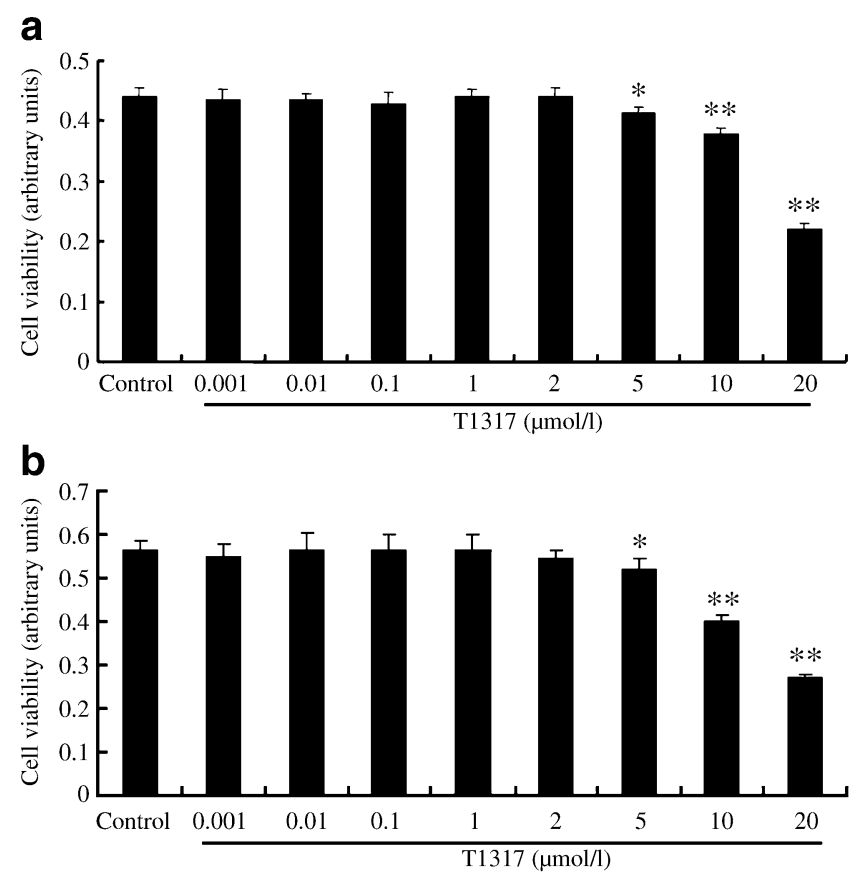

Fig. 2 LXR activation inhibits pancreatic beta cell viability. HIT-T15 (a) and MIN6 (b) cells, seeded in 96 well plates at a concentration of $1 \times 10^{4}-2 \times 10^{4}$ cells per well, were treated without (control) or with different concentrations of T1317 for $48 \mathrm{~h}$. Each well was then supplemented with $10 \mu \mathrm{l}$ MTT and incubated for $4 \mathrm{~h}$ at $37^{\circ} \mathrm{C}$. The medium was then removed, and $150 \mu \mathrm{l}$ DMSO was added to solubilise the MTT formazan. The optical density was read at $570 \mathrm{~nm}$ to evaluate cell viability. Values are the means \pm SEM of three individual experiments. ${ }^{*} p<0.05, * * p<0.01$ vs control 


\section{Results}

Lxr $\alpha$ and $\operatorname{Lxr} \beta$ are expressed and the receptor proteins transactivate the LXRE in HIT-T15 and MIN6 cells

Using real-time RT-PCR assays, we found that both $\operatorname{Lx} \alpha$ and $\operatorname{Lxr} \beta$ mRNA were present in mouse MIN6 cells and that $\operatorname{Lxr} \beta$ was more abundantly expressed than $\operatorname{Lxr} \alpha$ (Fig. 1a). In recent studies, levels of both $\operatorname{Lxr} \alpha$ and $L x r \beta$ mRNA were elevated in pancreatic islets of rodent models of diabetes [16]. Interestingly, in the present study, as shown in Fig. 1a, we found that levels of both $\operatorname{Lxr} \alpha$ and $\operatorname{Lxr} \beta$ mRNA were significantly upregulated by treatment with an LXR agonist (T1317, $10 \mu \mathrm{mol} / \mathrm{l})$. To determine whether LXRs are functionally active in pancreatic beta cells, transient transfection and luciferase reporter assays were performed in HIT-T15 and MIN6 cells. As depicted in Fig. $1 \mathrm{~b}$ and c, T1317 dose-dependently increased LXR response element (LXRE) reporter gene activity in both HIT-T15 and MIN6 cells, with maximum induction occurring at a concentration of $10 \mu \mathrm{mol} / 1$ (increases of $134 \%$ and $104 \%$ vs control, respectively, $p<0.01$ ). When the concentration of LXR agonist was increased to $20 \mu \mathrm{mol} / 1$, there was a (non-significant) decrease in LXRE reporter gene activity relative to that seen at $10 \mu \mathrm{mol} / \mathrm{l}$, which may indicate cell toxicity. Therefore, $20 \mu \mathrm{mol} / 1$ was used as the highest concentration for LXR agonists in further studies. In addition, in HIT-T15 and MIN6 cells the elevations in LXRE reporter gene activity in the presence of T1317
(10 $\mu \mathrm{mol} / \mathrm{l})$ were further markedly increased by cotransfection of the $\operatorname{Lxr} \alpha$ or $\operatorname{Lxr} \beta$ expression plasmid with the LXRE $\times 3$-TK-LUC construct $(p<0.01$ vs corresponding responses in cells cotransfected with control vector pcDNA3 and treated with $10 \mu \mathrm{mol} / 1$ T1317; Fig. 1d,e). Similar results were obtained with GW3965, another highly selective synthetic LXR agonist (ESM Fig. 1). Moreover, T1317 (at concentrations ranging from 5 to $20 \mu \mathrm{mol} / \mathrm{l}$ ) significantly induced the expression of typical LXR target genes Srebplc (also known as Srepf1) and Abcal $(p<0.01$, Fig. 1f) in MIN6 cells. These data suggest that LXRs are functionally active in pancreatic beta cells, and the presence of T1317 or GW3965 indicate that our findings are essentially LXR specific.

\section{LXR activation inhibits pancreatic beta cell proliferation}

Maintenance of beta cell mass is critical for secretion of adequate amounts of insulin [1, 2]. To investigate the functional consequences of LXR activation in pancreatic beta cells, cell viability was determined using MTT assays. T1317 inhibited the viability of HIT-T15 and MIN6 cells in a dose-dependent manner (Fig. 2a,b). Furthermore, GW3965 exerted an effect similar to T1317 (results not shown). It has been reported that LXR agonists suppress proliferation of different cell types [17, 18]. To further examine the effects of LXR activation on pancreatic beta cell growth, two different methods were used. Determina-
Fig. 3 Activation of LXRs inhibits beta cell proliferation. HIT-T15 (a, c, d) and MIN6 (b, e) cells were treated without (control) or with the indicated concentrations of T1317 or GW3965. Cell number (a, b) was determined using DNA fluorometric assays by measuring DNA content with the fluorescent dye Hoechst 33258. DNA synthesis was analysed using BrdU labelling assays (c, d, e). Representative micrographs of BrdU labelling assays in HIT-T15 cells are shown in (c) $($ scale bar $=150 \mu \mathrm{m})$. The data shown are the means \pm SEM of three separate experiments. ${ }^{*} p<0.05,{ }^{* *} p<0.01$ vs control
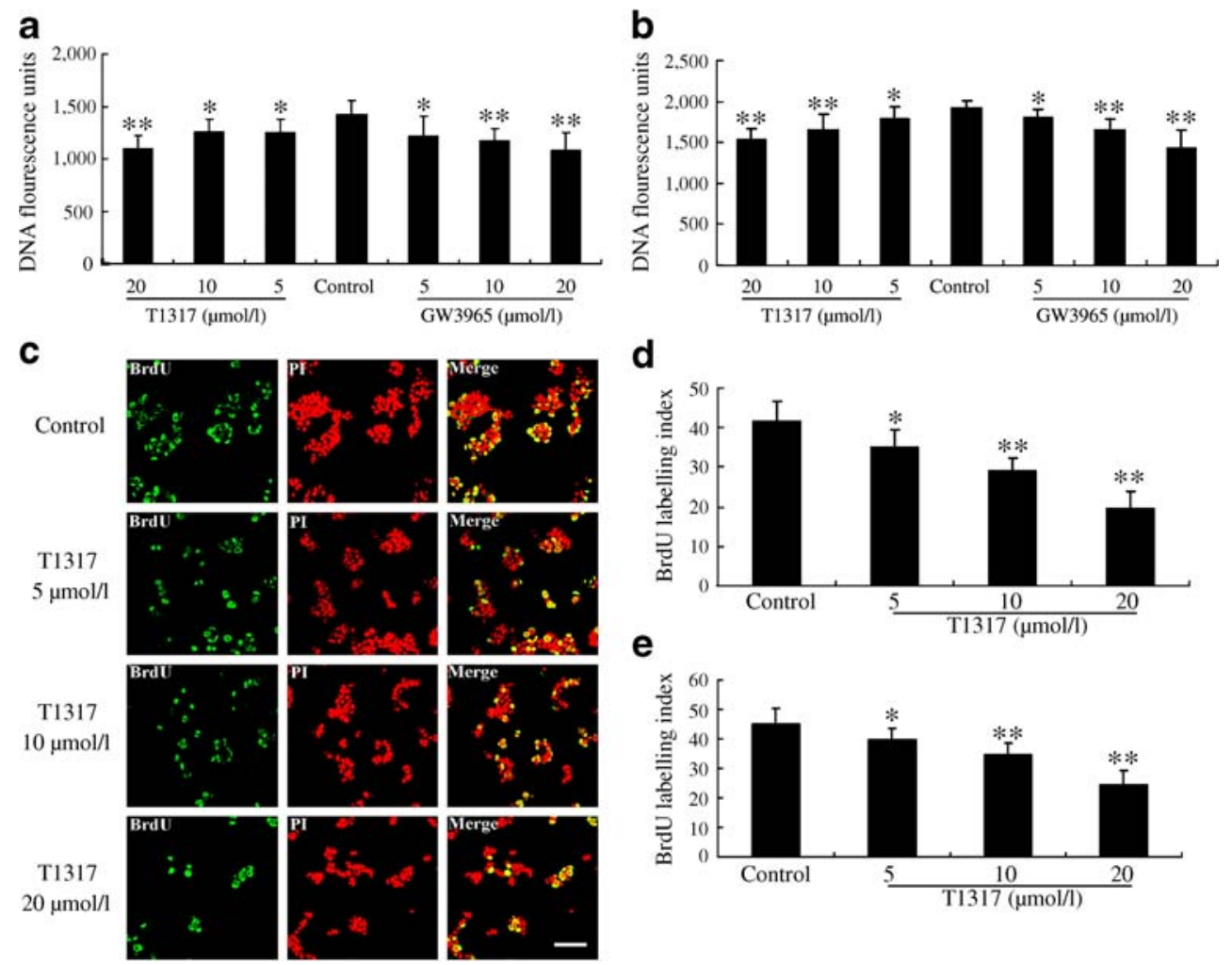

d

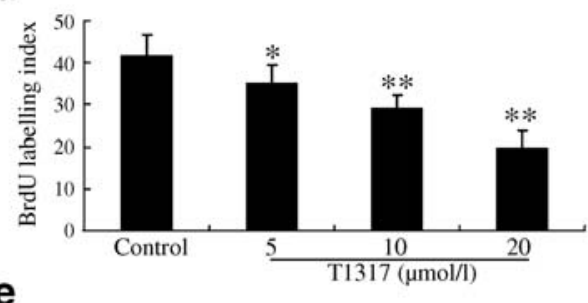

e

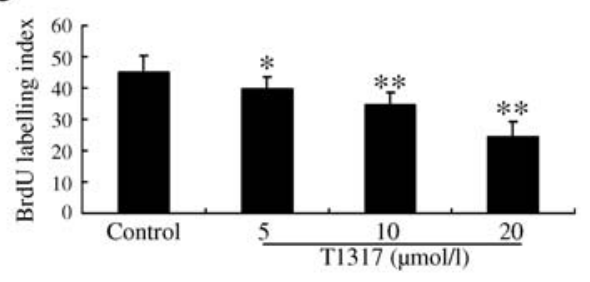


tion of DNA content by the addition and measurement of the fluorescent dye Hoechst 33258 indicated that LXR agonists dose-dependently reduced the cell number in both HIT-T15 and MIN6 cell lines (Fig. 3a,b). BrdU labelling indexes, which reflect the DNA synthesis and cell proliferation rates, were significantly reduced in T1317-treated HIT-T15 and MIN6 cells in a dose-dependent manner (Fig. 3c-e). Taken together, these results suggest that activation of LXRs inhibits pancreatic beta cell viability and proliferation.

LXR activation induces cell cycle arrest in pancreatic beta cells

We next investigated the mechanism by which LXR activation inhibits pancreatic beta cell proliferation. Using propidium iodide staining and flow cytometry analysis, we assessed the effects of LXR agonists on beta cell viability and cell cycle distributions. As depicted in Fig. 4a and b, treatment of HIT-T15 cells with T1317 for $48 \mathrm{~h}$ significantly increased the percentage of cells in G1 phase but

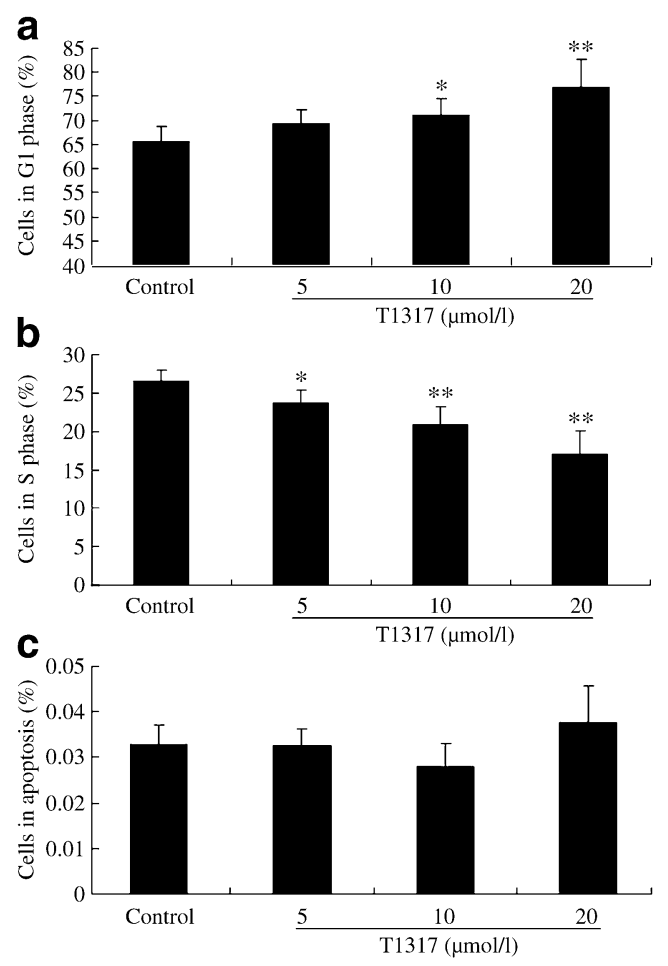

Fig. 4 LXR activation induces cell cycle arrest at the G1 phase in pancreatic beta cells. After treatment with the concentrations of T1317 indicated, HIT-T15 cells were harvested and fixed with $1 \mathrm{ml}$ of $75 \%$ ice-cold ethanol at $-20^{\circ} \mathrm{C}$ overnight. The next morning, cells were washed in PBS and stained with $500 \mu$ of propidium iodide solution $(50 \mu \mathrm{g} / \mathrm{ml}$ in PBS) containing $25 \mu \mathrm{g} / \mathrm{ml}$ of RNase. Then cell cycle distribution was investigated using flow cytometry analyses. The percentages of total cells in the G1 phase (a), S phase (b) and apoptosis (c) are shown as the means \pm SEM of three separate experiments. ${ }^{*} p<0.05,{ }^{* *} p<0.01$ vs control decreased the percentage of cells in $\mathrm{S}$ phase in a dosedependent manner. However, no visible apoptosis was observed in response to T1317 treatment (Fig. 4c). These results suggest that activation of LXRs induces pancreatic beta cell cycle arrest at the G1 phase.

LXR activation upregulates $\mathrm{p} 27$ protein production in beta cells and isolated mouse islets

In mammals, progression of the cell cycle from the $\mathrm{G} 1$ to $\mathrm{S}$ phase is governed by various genes [7]. To further elucidate the mechanism involved in cell cycle arrest by LXRs in beta cells, the effect of LXR activation on the mRNA levels of genes known to control G1 to S phase progression were determined using real-time RT-PCR assays. Surprisingly, the level of $S k p 2$ mRNA was clearly decreased by T1317 $(10 \mu \mathrm{mol} / \mathrm{l})$ treatment (49\% decrease, $p<0.01$; Fig. 5a), whereas other mRNA levels were not significantly affected. It has been reported that the SKP2-mediated proteolytic pathway plays a critical role in regulating $\mathrm{p} 27$ protein levels in beta cells $[8,9,11]$. We therefore treated HIT-T15 and MIN6 cells with different concentrations of T1317 and determined the p27 protein levels by western blot analysis. As shown in Fig. 5b and c, T1317 dose-dependently increased the p27 protein levels in HIT-T15 and MIN6 cells and isolated mouse islets. However, the p27 (also known as $C d k n 1 b$ ) mRNA level was not altered by T1317 treatment (Fig. 5a), indicating that activation of LXRs upregulated the cellular level of p27 via a post-translational mechanism. To confirm this hypothesis, we examined the stability of the p27 protein after T1317 $(10 \mu \mathrm{mol} / \mathrm{l})$ treatment, using cycloheximide $(50 \mu \mathrm{g} / \mathrm{ml})$ to block de novo protein synthesis. As expected, the rate of $\mathrm{p} 27$ protein degradation was significantly decreased in HIT-T15 cells treated with T1317 (Fig. 5d).

p27 knockdown reverses the growth inhibition and cell cycle arrest effects of LXR activation

It has been reported that a relatively high dose of T1317 may have off-target effects [30]. To confirm that the effects of the LXR agonists used in this study were mediated by LXR activation, adenovirus-based RNA interference (RNAi) was used to knockdown LXR $\alpha$ and LXR $\beta$ in beta cells. As shown in ESM Fig. 2a and b, the expression of $L x r \alpha$ and $L x r \beta$ was suppressed by about $71 \%$ and $76 \%$, respectively, by coinfection of MIN6 cells with adenoviruses expressing $L X R \alpha$ siRNA and $L X R \beta$ siRNA compared with control siRNA adenovirus-infected MIN6 cells. Inhibition of $\operatorname{Lxr} \alpha$ and $\operatorname{Lxr} \beta$ expression abolished the ability of T1317 $(10 \mu \mathrm{mol} / \mathrm{l})$ to upregulate levels of p27 and induce cell cycle arrest in beta cells (ESM Fig. 2c-f). To further verify the functional involvement of p27 in cell 
a

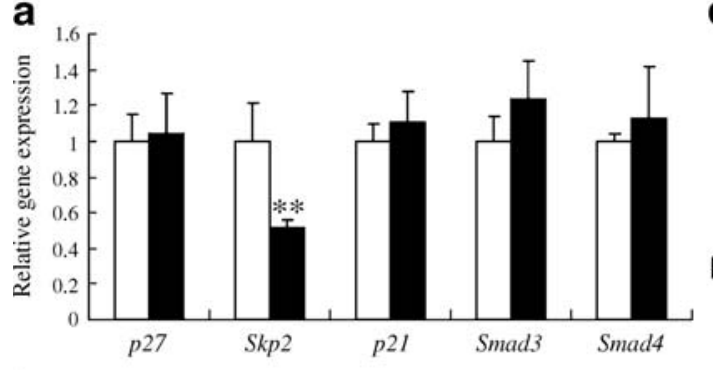

b

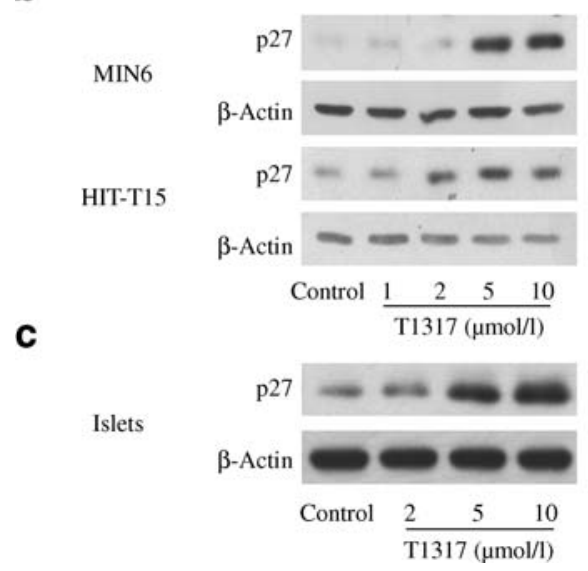

d
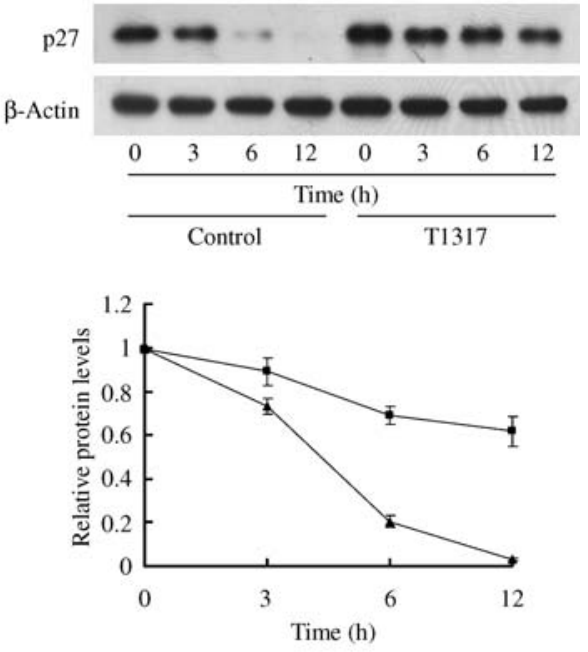

treated without (control) or with $\mathrm{T} 1317(10 \mu \mathrm{mol} / \mathrm{l})$ for $48 \mathrm{~h}$, at which time cycloheximide $(50 \mu \mathrm{g} / \mathrm{ml})$ was added for the indicated periods of time. All the treated cells were then harvested and lysed for western blot analyses to determine the protein levels of p27 and $\beta$-actin (as a loading control). Representative immunoblots and a graph showing protein levels of p27 relative to $\beta$-actin (triangles, control; squares, T1317) are shown (d). Data are the means \pm SEM of three separate experiments

of beta cell mass, but has no obvious effect under normal physiological conditions $[8,9]$. Concordant with these results, as shown in Fig. 6d, p27 knockdown reversed the inhibition of $\left[{ }^{3} \mathrm{H}\right]$ thymidine by $\mathrm{T} 1317(10 \mu \mathrm{mol} / \mathrm{l})$ in isolated mouse islets. However, $p 27$ siRNA alone had no significant effect on the growth of mouse islets. Furthermore, adenovirus-based $p 27$ siRNA was used to efficiently knockdown levels of both $p 27$ mRNA and the protein in MIN6 cells (results not shown), and p27 knockdown almost completely reversed the T1317-induced cell cycle arrest at the G1 phase (Fig. 7). These data implicate that the effects of LXR agonists in this study were dependent upon the expression or the LXR genes, and p27 is an important mediator of cell cycle arrest and growth inhibition by LXR activation. As depicted in Fig. 6d, T1317 $(10 \mu \mathrm{mol} / \mathrm{l})$ significantly inhibited the $\left[{ }^{3} \mathrm{H}\right]$ thymidine incorporation rate in isolated mouse islets ( $37 \%$ decrease, $p<0.01)$, indicating that LXR activation also decreased the proliferation rate and the percentage of cells in $\mathrm{S}$ phase in primary mouse islets. Previous studies have shown that the p27 levels within beta cells plays an essential role in translating metabolic demands or other environmental treatments into regulation

\section{Discussion}

Type 2 diabetes is a chronic metabolic syndrome caused by insulin deficiency. The mechanisms involved are not fully understood; however, it is apparent that inadequate func- 
a

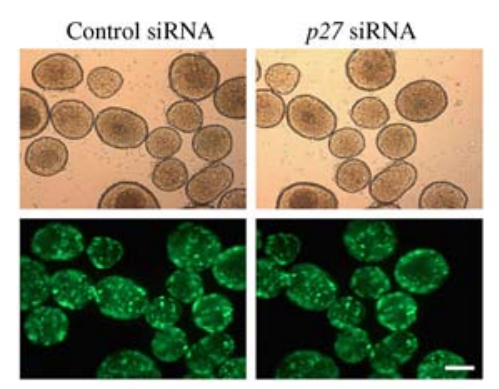

b

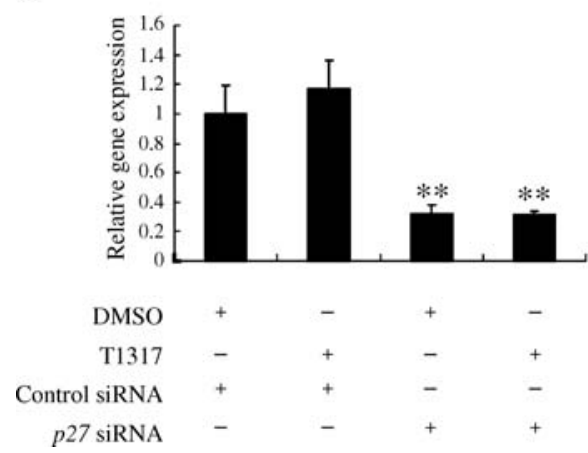

Fig. 6 Knockdown of p27 reverses LXR activation-induced growth inhibition. Isolated mouse islets were infected with adenoviruses expressing control siRNA or $p 27$ siRNA and treated with vehicle (DMSO) or T1317 $(10 \mu \mathrm{mol} / \mathrm{l})$ for $48 \mathrm{~h}$. a Both the $p 27$ and control siRNA adenoviral vectors coexpressed GFP. Representative graphs of islets infected with indicated adenoviruses for $48 \mathrm{~h}$ are shown (scale bar $=100 \mu \mathrm{m}$ ). Levels of p27 mRNA and p27 protein were determined by real-time RT-PCR (b) and western blot analyses (c), respectively, to assess the knockdown potencies of these adenovirus-based RNAi, using the corresponding levels of $\beta$-actin as the references. d p27

tional beta cell mass is important. Several lines of evidence indicate that dysregulation of beta cell proliferation is a fundamental feature in the pathogenesis of type 2 diabetes $[1,5]$. Beta cell mass is dynamic, changing throughout the development of type 2 diabetes. During the early stages of this disease, beta cell mass increases via proliferation to compensate for the increased insulin demand that results from insulin resistance. As the development of insulin resistance progresses during the later stage of type 2 diabetes, beta cells fail to further proliferate in the face of progressive increases in blood glucose and lipid levels (hyperglycaemia and hyperlipidaemia). Eventually, fullblown diabetes ensues.

LXRs are activated by naturally produced oxysterols and synthetic compounds such as T1317 and GW3965 [31], and have emerged as important regulators of lipid and lipoprotein metabolism [32]. However, the role of LXRs in metabolic regulation has yet to be fully established. It has previously been reported that administration of synthetic LXR agonist improved glucose tolerance in a murine model of diet-induced obesity and insulin resistance, and LXR stimulation reduced serum glucose in diabetic $d b / d b$ mice and Zucker diabetic fatty (ZDF) rats [32, 33]. In contrast,
C

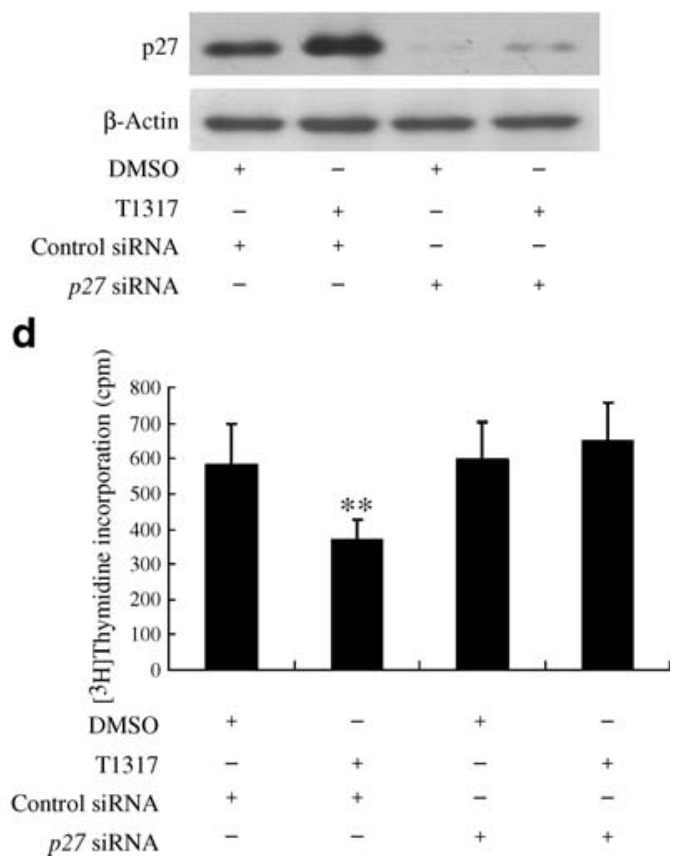

RNAi reversed the inhibition $\left[{ }^{3} \mathrm{H}\right]$ thymidine incorporation by LXR activation. During the last $24 \mathrm{~h}$ of $\mathrm{T} 1317$ treatment, $\left[{ }^{3} \mathrm{H}\right]$ thymidine at $37 \mathrm{kBq} / \mathrm{ml}$ was added to each well. The islets were washed twice with PBS after the culture period and sonicated in $10 \mathrm{mmol} / \mathrm{l}$ Tris- $\mathrm{HCl} /$ $5 \mathrm{mmol} / \mathrm{l}$ EDTA. DNA was precipitated and trapped as described in the Methods. Radioactivity was counted after the addition of scintillation fluid. The data shown are the means \pm SEM of three separate experiments. ${ }^{* *} p<0.01$ vs corresponding responses in cells infected with control siRNA and treated with DMSO (the first bar on the left of each graph)

Chisholm et al. [14] demonstrated that the LXR agonist T1317 induced severe lipogenesis and insulin resistance in $d b / d b$ diabetic mice. Furthermore, LXR-deficient mice exhibited improved metabolic control [15]. These results indicate that LXR can exert different effects on metabolic regulation depending on the level and duration of LXR activation and/or other environmental conditions. Previous studies have reported that both $\operatorname{Lxr} \alpha$ and $\operatorname{Lxr} \beta$ mRNA levels are significantly elevated in the pancreatic islets of animal models of type 2 diabetes [16]. In this study we found that both $\operatorname{Lxr} \alpha$ and $\operatorname{Lxr} \beta$ mRNA was present and significantly upregulated by the addition of LXR agonists to beta cells, suggesting that LXR elevation might be involved in pancreatic beta cell dysfunction in type 2 diabetes. Moreover, levels of oxysterols, endogenous activators of LXRs, are markedly upregulated in the blood plasma of patients with type 2 diabetes $[34,35]$. Importantly, Mitro et al. [36] demonstrated that glucose also activates LXRs at physiological concentrations. During the development of type 2 diabetes, both blood glucose and lipid (including oxysterol) levels progressively increase. All these data suggest that, during type 2 diabetes development, the activation and transcriptional activity of LXRs are upregu- 


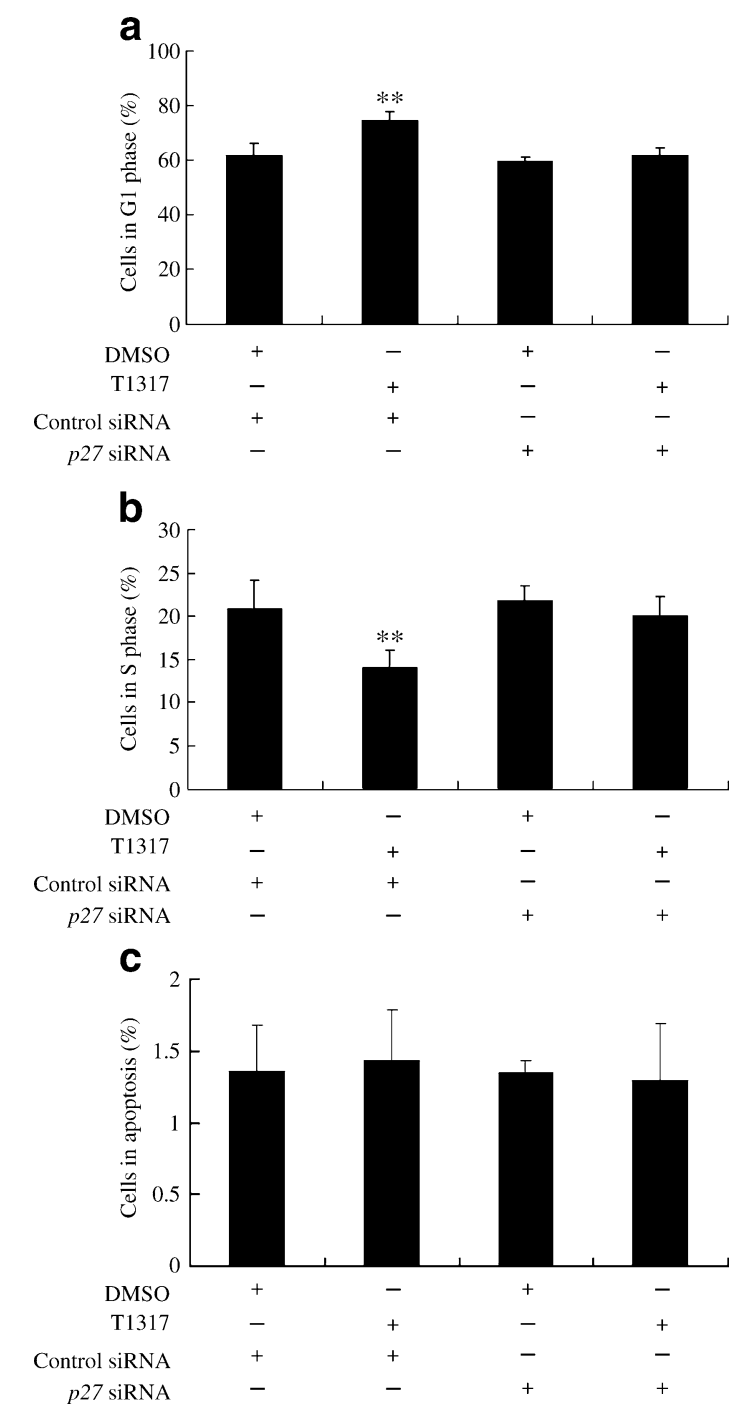

Fig. 7 Knockdown of p27 partially reverses LXR activation-induced cell cycle arrest in MIN6 cells. After infecting with adenoviruses expressing control siRNA or p27 siRNA and treating with vehicle (DMSO) or T1317 $(10 \mu \mathrm{mol} / \mathrm{l})$ for $48 \mathrm{~h}$, MIN6 cells were harvested and fixed with $1 \mathrm{ml}$ of $75 \%$ ice-cold ethanol at $-20^{\circ} \mathrm{C}$ overnight. The next morning, cells were washed in PBS and stained with $500 \mu \mathrm{l}$ of propidium iodide solution ( $50 \mu \mathrm{g} / \mathrm{ml}$ in PBS) containing $25 \mu \mathrm{g} / \mathrm{ml}$ of RNase. Then cell cycle distribution was investigated using flow cytometry analyses. The percentages of total cells in the G1 phase (a), $\mathrm{S}$ phase (b) and apoptosis (c) are shown as the means \pm SEM of three separate experiments. ${ }^{*} p<0.01$ vs corresponding responses in cells infected with control siRNA and treated with DMSO (the first bar on the left of each graph)

lated accordingly. Although LXRs are important regulators of fatty acid metabolism and insulin secretion under physiological conditions [13, 37], chronic aberrant activation of LXRs may result in deleterious effects on the organism. Consistent with this hypothesis, in the present study we found that the LXR genes were expressed and transactivated LXRE in HIT-T15 and MIN6 cells, and chronic activation of LXRs inhibited beta cell proliferation through cell cycle arrest.
Several factors have recently been implicated in the regulation of beta cell cycle progression and beta cell mass maintenance [10]. The cyclin-dependent kinase inhibitor p27 has recently been recognised as an important regulator of beta cell cycle transition and proliferation $[8,9,11]$. Protein levels of p27 have been shown to be regulated at transcriptional and post-translational levels. In pancreatic beta cells, the SKP2-mediated post-translational ubiquitin proteolytic pathway plays an essential role in regulating the cellular abundance of p27 [8]. In this study we found that that LXR activation induced cell cycle arrest at the G1 phase in pancreatic beta cells. Meanwhile, activation of LXRs obviously decreased $S k p 2$ mRNA levels and upregulated p27 protein levels in beta cells. In addition, the rate of p27 protein degradation was significantly decreased in beta cells treated with T1317. However, the p27 mRNA level did not change in response to treatment with T1317 (Figs 5a,d, 6b), indicating that LXR activation may upregulate the p27 level primarily through a post-translational mechanism. However, the precise role of SKP2 in this process remains to be clarified. To further investigate the involvement of p27 upregulation in LXR activationinduced cell cycle arrest in pancreatic beta cells, we introduced adenovirus-based RNAi for targeted knockdown of p27 in isolated mouse islets and MIN6 cells. Knockdown of p27 almost completely prevented the effects of LXR activation on $\left[{ }^{3} \mathrm{H}\right]$ thymidine incorporation and cell cycle arrest. Based on these results, we conclude that aberrant activation of LXR-induced cell cycle arrest and growth inhibition, at least partly through an increase in p27 levels, may account for the deficient beta cell mass that results in uncontrolled diabetes, although further studies are need to confirm the role of this pathway in vivo.

Increased apoptosis induced by hyperglycaemia and/or hyperlipidaemia has been implicated as an important mechanism for beta cell mass inadequacy in type 2 diabetes $[1,3]$. However, once thought incapable of significant proliferation, pancreatic beta cells have recently been shown to have an immense capacity for self-renewal [4, 10]. There is growing evidence to suggest that beta cell mass is maintained by the replication of differentiated beta cells in adult rodents and that all beta cells contribute equally to the growth and maintenance of beta cell mass $[6$, 38]. These results suggest that both increased apoptosis and deficient self-proliferation are very important for beta cell mass impairment in type 2 diabetes. At the time our experiments were being conducted, Wente et al. [39] published a paper demonstrating that activation by a combination of LXRs and RXRs induced growth arrest and apoptosis in MIN6 cells and isolated rat islets, whereas LXR activation alone had no effect. Meanwhile, Choe et al. [16] reported that chronic activation of LXRs by T1317 induced cell apoptosis in rat INS-1 cells and isolated rat 
islets. However, in the present study we demonstrated that activation of LXRs inhibits pancreatic beta cell proliferation through cell cycle arrest in hamster HIT-T15 cells, mouse MIN6 cells and isolated mouse islets. Different levels and durations of LXR activation and species-specific difference in the response to agonists may account for the different effects of LXRs on beta cell growth [40, 41]. Nevertheless, the different mechanisms demonstrated by previous studies and ours may help us to fully understand the causes of beta cell dysfunction in type 2 diabetes.

In conclusion, we report for the first time that activation of LXRs induced cell cycle arrest and growth inhibition in pancreatic beta cells. Stabilisation and upregulation of levels of p27 may mediate the effects of LXR activation on beta cell proliferation. Our studies contribute to the understanding of the mechanisms responsible for the inadequate functional beta cell mass in type 2 diabetes and point to targets for possible interventions during the development of this disorder.

Acknowledgements This work was supported by grants from the National Natural Science Foundation of China (30771041) and the Special Funds for Major State Basic Research Program of China (973 Program, 2006CB503908) to X. Han.

Duality of interest The authors declare that there is no duality of interest associated with this manuscript.

\section{References}

1. Saltiel AR (2001) New perspectives into the molecular pathogenesis and treatment of type 2 diabetes. Cell 104:517-529

2. Del Guerra S, Lupi R, Marselli L et al (2005) Functional and molecular defects of pancreatic islets in human type 2 diabetes. Diabetes 54:727-735

3. Prentki M, Nolan CJ (2006) Islet beta cell failure in type 2 diabetes. J Clin Invest 116:1802-1812

4. Cozar-Castellano I, Fiaschi-Taesch N, Bigatel TA et al (2006) Molecular control of cell cycle progression in the pancreatic betacell. Endocr Rev 27:356-370

5. Ackermann AM, Gannon M (2007) Molecular regulation of pancreatic beta-cell mass development, maintenance, and expansion. J Mol Endocrinol 38:193-206

6. Brennand K, Huangfu D, Melton D (2007) All beta cells contribute equally to islet growth and maintenance. PLoS Biol 5:e163

7. Rane SG, Reddy EP (2000) Cell cycle control of pancreatic beta cell proliferation. Front Biosci 5:D1-D19

8. Zhong L, Georgia S, Tschen SI, Nakayama K, Nakayama K, Bhushan A (2007) Essential role of Skp2-mediated p27 degradation in growth and adaptive expansion of pancreatic beta cells. J Clin Invest 117:2869-2876

9. Uchida T, Nakamura T, Hashimoto N et al (2005) Deletion of Cdkn1b ameliorates hyperglycemia by maintaining compensatory hyperinsulinemia in diabetic mice. Nat Med 11:175-182

10. Heit JJ, Karnik SK, Kim SK (2006) Intrinsic regulators of pancreatic beta-cell proliferation. Annu Rev Cell Dev Biol 22:311-338

11. Georgia S, Bhushan A (2006) p27 regulates the transition of betacells from quiescence to proliferation. Diabetes 55:2950-2956
12. Janowski BA, Willy PJ, Devi TR, Falck JR, Mangelsdorf DJ (1996) An oxysterol signalling pathway mediated by the nuclear receptor LXR alpha. Nature 383:728-731

13. Steffensen KR, Gustafsson JA (2004) Putative metabolic effects of the liver X receptor (LXR). Diabetes 53(Suppl 1):S36-S42

14. Chisholm JW, Hong J, Mills SA, Lawn RM (2003) The LXR ligand T0901317 induces severe lipogenesis in the $\mathrm{db} / \mathrm{db}$ diabetic mouse. J Lipid Res 44:2039-2048

15. Schuster GU, Johansson L, Kietz S, Stulnig TM, Parini P, Gustafsson JA (2006) Improved metabolic control by depletion of liver X receptors in mice. Biochem Biophys Res Commun 348:176-182

16. Choe SS, Choi AH, Lee JW et al (2007) Chronic activation of liver $\mathrm{X}$ receptor induces beta-cell apoptosis through hyperactivation of lipogenesis: liver $\mathrm{X}$ receptor-mediated lipotoxicity in pancreatic beta-cells. Diabetes 56:1534-1543

17. Fukuchi J, Kokontis JM, Hiipakka RA, Chuu CP, Liao S (2004) Antiproliferative effect of liver $\mathrm{X}$ receptor agonists on LNCaP human prostate cancer cells. Cancer Res 64:7686-7689

18. Blaschke F, Leppanen O, Takata Y et al (2004) Liver X receptor agonists suppress vascular smooth muscle cell proliferation and inhibit neointima formation in balloon-injured rat carotid arteries. Circ Res 95:e110-e123

19. Miyazaki J, Araki K, Yamato E et al (1990) Establishment of a pancreatic beta cell line that retains glucose-inducible insulin secretion: special reference to expression of glucose transporter isoforms. Endocrinology 127:126-132

20. Santerre RF, Cook RA, Crisel RM et al (1981) Insulin synthesis in a clonal cell line of simian virus 40-transformed hamster pancreatic beta cells. Proc Natl Acad Sci USA 78:4339-4343

21. Han X, Sun Y, Scott S, Bleich D (2001) Tissue inhibitor of metalloproteinase-1 prevents cytokine-mediated dysfunction and cytotoxicity in pancreatic islets and beta-cells. Diabetes 50:1047-1055

22. Sabol SL, Brewer HB Jr, Santamarina-Fojo S (2005) The human ABCG1 gene: identification of LXR response elements that modulate expression in macrophages and liver. J Lipid Res 46:2151-2167

23. Li WQ, Jiang Q, Aleem E, Kaldis P, Khaled AR, Durum SK (2006) IL-7 promotes T cell proliferation through destabilization of p27Kip1. J Exp Med 203:573-582

24. Seo JB, Moon HM, Kim WS et al (2004) Activated liver $\mathrm{X}$ receptors stimulate adipocyte differentiation through induction of peroxisome proliferator-activated receptor gamma expression. Mol Cell Biol 24:3430-3444

25. Huq MD, Tsai NP, Gupta P, Wei LN (2006) Regulation of retinal dehydrogenases and retinoic acid synthesis by cholesterol metabolites. EMBO J 25:3203-3213

26. Shen C, Buck AK, Liu X, Winkler M, Reske SN (2003) Gene silencing by adenovirus-delivered siRNA. FEBS Lett 539:111114

27. He TC, Zhou S, da Costa LT, Yu J, Kinzler KW, Vogelstein B (1998) A simplified system for generating recombinant adenoviruses. Proc Natl Acad Sci USA 95:2509-2514

28. Meng ZX, Sun JX, Ling JJ et al (2006) Prostaglandin E2 regulates Foxo activity via the Akt pathway: implications for pancreatic islet beta cell dysfunction. Diabetologia 49:2959-2968

29. Rago R, Mitchen J, Wilding G (1990) DNA fluorometric assay in 96-well tissue culture plates using Hoechst 33258 after cell lysis by freezing in distilled water. Anal Biochem 191:31-34

30. Mitro N, Vargas L, Romeo R, Koder A, Saez E (2007) T0901317 is a potent PXR ligand: implications for the biology ascribed to LXR. FEBS Lett 581:1721-1726

31. Chen W, Chen G, Head DL, Mangelsdorf DJ, Russell DW (2007) Enzymatic reduction of oxysterols impairs LXR signaling in cultured cells and the livers of mice. Cell Metab 5:73-79

32. Laffitte BA, Chao LC, Li J et al (2003) Activation of liver X receptor improves glucose tolerance through coordinate regulation 
of glucose metabolism in liver and adipose tissue. Proc Natl Acad Sci USA 100:5419-5424

33. Cao G, Liang Y, Broderick CL et al (2003) Antidiabetic action of a liver $\mathrm{x}$ receptor agonist mediated by inhibition of hepatic gluconeogenesis. J Biol Chem 278:1131-1136

34. Murakami H, Tamasawa N, Matsui J, Yasujima M, Suda T (2000) Plasma oxysterols and tocopherol in patients with diabetes mellitus and hyperlipidemia. Lipids 35:333-338

35. Ferderbar S, Pereira EC, Apolinario E et al (2007) Cholesterol oxides as biomarkers of oxidative stress in type 1 and type 2 diabetes mellitus. Diabetes Metab Res Rev 23:35-42

36. Mitro N, Mak PA, Vargas L et al (2007) The nuclear receptor LXR is a glucose sensor. Nature 445:219-223

37. Zitzer H, Wente W, Brenner MB et al (2006) Sterol regulatory element-binding protein 1 mediates liver $\mathrm{X}$ receptor-beta-induced increases in insulin secretion and insulin messenger ribonucleic acid levels. Endocrinology 147:3898-3905

38. Cano DA, Rulifson IC, Heiser PW et al (2008) Regulated beta-cell regeneration in the adult mouse pancreas. Diabetes 57:958-966

39. Wente W, Brenner MB, Zitzer H, Gromada J, Efanov AM (2007) Activation of liver $\mathrm{X}$ receptors and retinoid $\mathrm{X}$ receptors induces growth arrest and apoptosis in insulin-secreting cells. Endocrinology 148:1843-1849

40. Eizirik DL, Pipeleers DG, Ling Z, Welsh N, Hellerstrom C, Andersson A (1994) Major species differences between humans and rodents in the susceptibility to pancreatic beta-cell injury. Proc Natl Acad Sci USA 91:9253-9256

41. Zawalich WS, Bonnet-Eymard M, Zawalich KC (1998) Glucoseinduced desensitization of the pancreatic beta-cell is species dependent. Am J Physiol 275:E917-E924 